\title{
Event Competitivness in Heritage Tourism in Rural Croatia
}

\author{
Danijel Drpić \\ Polytechnic of Rijeka, Croatia \\ ddrpic@veleri.hr \\ Elena Rudan \\ Faculty of Tourism and Hospitality Management Opatija, Croatia \\ elenar@fthm.hr
}

In recent few years, Croatia's rural areas have been developing various forms of tourism, primarily focused on heritage. Sustainable management of the rich cultural and historical heritage of Croatian rural areas can stimulate the creation of market recognition and competitiveness. Among the critical elements of heritage tourism are the events stemming from the community and its traditions, and which represent that community on the tourism market. Heritage-based events enable the creation of a unique tourism product that, through heritage elements, enables the promotion of Croatian rural destinations, respecting their characteristics and uniqueness. Tourism events and programs provide a successful interpretation of heritage elements, strengthening local identity and creating positive interrelationships between visitors and hosts. This paper aims to explore and propose possibilities for innovation of heritage-based events in rural areas of Croatia, with analysis of an event held in Đakovo: the Đakovo Embroidery Festival. In order to facilitate the competitiveness of Croatian heritage-based cultural events, the paper proposes an event certification model: the CroRuralisHeritage Awards Certification Model. The paper also provides guidelines for the creation of heritage-based tourism events as a vital element in the realisation of innovative and sustainable tourism services to achieve the competitiveness of rural Croatian tourism.

Keywords: heritage, events, sustainable development, rural tourism, Croatia, Đakovo Embroidery

https://doi.org/10.26493/2335-4194.12.161-172

\section{Introduction}

Rural areas have many distinctive features that distinguish them from other, primarily coastal and urban, tourist destinations and that are reflected in their focus on agriculture, unique cultural and historical heritage and the specificity of gastronomic and oenological offerings. In recent decades, rural areas have become increasingly interesting tourist destinations, not only in Croatia but also throughout Europe. According to Eu- rostat data (2017a), rural areas in Croatia occupy $79.1 \%$ of the total territory, with $45.9 \%$ of its population. According to Demonja (2014), the rural area in Croatia is determined by the territorial division according to which small administrative units, municipalities, are considered as rural areas and cities as urban ones. This paper explores rural areas of the mainland of Croatia.

In considering tourism development, it is necessary to enable the rural areas to evaluate and protect 
tangible and intangible heritage and achieve dynamic economic development. Local community values need to be managed sustainably, without disturbing the existing resource base of the rural area and ensuring economic and social benefits for all destination stakeholders (Daniloska \& Hadzi Naumova-Mihajlovska, 2015). As an essential stakeholder, the local population is generally more prone to tourism development based on authentic culture, since it is not something unknown, but rather part of their identity of which they are, in principle, proud. Of course, sustainable development principles must be considered, and excessive and unprofessional refinement of culture must be avoided (Sedmak, Planinc, Kociper \& Planinc, 2015). Due to the development of modern information technologies, new guidelines in tourism development considerations and the growing interest of tourists in traditions, particular forms of events offered by rural areas are becoming tourists' interest and motivation for travelling. In such new and contemporary conditions of tourism development, it is necessary to enable the creation of value-added offers, while preserving the originality of heritage elements as the basis for creating competitive tourism services in rural areas.

\section{Characteristics of Contemporary Tourism Demand in Croatian Rural Tourism}

Knowledge of the socio-demographic structure of visitors, their motives and habits are the basis for achieving the competitiveness of rural tourism destinations (Getz, 2010; Krajičkova \& Šauer, 2018). According to the United Nations World Tourism Organization (UNWTO), Europe was the most visited region in the world in 2016, accounting for about half $(49.8 \%)$ of the 1.24 billion arrivals of international tourists. The richness of European cultures, the diversity of its landscapes, and the quality of tourism infrastructure are probably the essential reasons why tourists will visit Europe in the future. Considering tourist traffic intensity in rural areas, Eurostat (2017b) indicators show that there are more nights spent in accommodation facilities in rural areas than in urban centres of the European Union (European Commission, 2017). Based on these assumptions, rural tourism management can successfully create a recognisable tourism product with significant added value. Added value for stakeholders is manifested in the numerous benefits of rural tourism development (economic, socio-demographic benefits, greater recognition, strengthening of selfawareness and identity) and in ensuring a permanent and sustainable rural development.

The existing tourism demand and supply in Croatian rural areas are not at a satisfactory level. Although the total number of tourists and overnight stays in the whole country is rising, rural areas do not show such intensity of growth and development. In 2016, there were 15,454 , 000 guests who realized 77,919,000 overnight stays; 2017 recorded a growth in tourism demand, with 17,430 , 000 arrivals, which is $12.8 \%$ more than 2016 and $86,200,000$ overnight stays or $10.6 \%$ more than in 2016. Looking at Croatia through its three regions (Adriatic, continental and the City of $\mathrm{Za}$ greb and Zagreb County), it can be said that the Adriatic part realized 14,399 ,000 arrivals $(82.61 \%$ of the total number) and 79,305,000 overnight stays ( $92 \%$ of the total); Zagreb County had 1,373,00o visitors (7.88\% of the total number) and 2,413,00o overnight stays (2.8\% of the total) and continental Croatia $1,658,000$ visitors (9.51\% of the total) and 4,482,00o overnight stays (5.20\% of total) (Ministry of Tourism, 2018).

Slavonia, Baranja, and Western Syrmia are economically less developed areas; they are largely emigrated from, and agricultural activity, once the leading economic activity in this region, faces serious problems due to various subjective and objective difficulties. The development of tourism in the area would enable the preservation and development of agriculture, preservation of tradition and local identity, as well as the creation of a new basis for economic and social revival. The stated can be achieved by incorporating heritage into the tourism product in different ways (including events) that would preserve the original heritage value and create new economic benefits. Since we are considering the rural areas of the Republic of Croatia, it is necessary to determine the competitive abilities of rural destinations.

\section{Competitiveness of Rural Tourism Destinations}

Although rural areas represent an abundant source of heritage elements and a rich resource base for the cre- 
ation of tourism offerings, they are unfortunately often not recognised as a valuable potential for tourism offer. Farming, crafts, traditional crafts, gastro-oenological offer, churches, traditional buildings and other elements form a set of heritage motifs that need to be uniquely presented on the tourism market, without disturbing their originality and distinctiveness. This is possible through tourism events. According to Svržnjak, Kasntar, Jerčinović, and Kamenjak (2014), rural tourism is a collective name for the activities and forms of tourism that develop in rural areas and is determined by the natural and cultural resources that are found there. 'Rural tourism' is a very broad term that signifies every tourist activity within a rural area, encompassing various forms of tourism (rural, ecotourism, cultural, rural household tourism, events, etc.).

Similarly, Kušen (2006) mentions that rural tourism is a complex type of tourism composed of different types of tourism and is defined by the features and boundaries of rural areas in which it develops. Dashper (2014) also points to the importance of rural tourism for rural areas, stating that rural tourism offers a possible solution to some of the problems associated with lost economic opportunities and population decline that accompany the waning of agriculture. Many governments and regional authorities have embraced rural tourism as an opportunity to bring new money into rural regions, stimulating growth, providing employment opportunities and thus beginning to halt rural decline (Smolčić Jurdana, 2015). In Croatia, rural tourism and the related activities started to be taken seriously as late as 1996, with the adoption of the Regulation on the provision of catering services in rural households, thus establishing a legal framework for action within the new tourism sector. This was ten years after the European Council had recognised rural tourism as a new form of tourism service that took place in rural areas. The first tourism-oriented rural households were registered in 1998, when there were 32 (Ružić, 2011), in 2014, there were 447 registered rural households, while today there are around 500. In terms of the structure of offerings, almost $80 \%$ of them are excursion sites (offering tasting rooms and visits to the estate), while only $20 \%$ offer accommodation services (Poslovni.hr, 2018). Although development over two decades has been noticeable, it is not proportional to the development potential of a country with a vibrant tourism tradition, almost $80 \%$ rural areas accompanied by the natural, cultural and environmental values of such area. The largest number of rural households is registered in Istria and Dubrovnik-Neretva County, already the most developed Croatian tourist regions. In the continental part of Croatia, there is a lack of accommodation capacities, as well as other rural-related services.

Tourism product development in a rural area is possible only by respecting its special features and by ensuring permanent protection of the resource base, sustainable development, and quality of offerings. These prerequisites can be met by creating unique tourism products: tourism events as the basis for tourism offerings in rural destinations. Their uniqueness is reflected in their continuous dynamic nature; they can be permanently improved and changed according to the needs of the local community and supply and demand, which is why events represent an ideal form of tourism product in rural areas.

\section{The Contribution of Events in Developing Rural Tourism Offer}

The scientific literature defines tourism events as an event, occasion, or case, but there are also synonyms such as occurrence, incident or experience that indicate different types of events or activities in the area, especially those more significant and easily memorable (Getz, 2010; Bowdin, Allen, O’Toole, Harris \& McDonnell, 2008; Ivančić, 2015). Tourism events are among the most critical factors in development strategies and competitiveness increase in many of the world's tourism destinations (Goeldner \& Ritchie, 2006; Davidson \& Rogers, 2006). Tourism events have a positive social, economic, and cultural impact on a potential event visitor (Getz \& Page, 2016, p. 54), affecting his/her level of satisfaction. Positive effects of tourism events are also crucial for the local community as they ensure sustainable well-being and growth of the overall life satisfaction in the destination (growth of standards, social quality of life, etc.) (Drpić, 2017).

A rural tourism destination is competitive when 
it develops its products and services on the tourism market in a way that ensures tourism consumption increase and that attracts a larger number of visitors, providing them with profitable, satisfactory, and unforgettable experiences while simultaneously increasing the well-being of the local population and preserving the natural capital of the destination for future generations. Gomezelj Omerzel (2006, p. 169) emphasises that the support of tourism stakeholders is essential for successful development and sustainability of tourism and could help to improve the destination competitiveness. From the above, it can be concluded that tourism destination competitiveness is largely based on sustainable development of basic resources, strengthening the overall economic performance of the whole community (Crouch \& Brent Ritchie, 2003), and the synergy of all stakeholders. Destination attractiveness depends primarily on four elements (Crouch \& Brent Ritchie, 1999; Porter, 1990): core resource base (culture, history, activities, special events, entertainment and superstructure), supporting factors (infrastructure, availability, offer, hospitality, companies), destination management (marketing, finance, capital, organization, human resource development, information/research, quality of services, visitor management) and qualitative determinants (location, independence, safety, image, brand, value for money).

From the aforementioned, it can be concluded that attractiveness influences tourism destination competitiveness, whose elements destination management can successfully present on the tourism market by using knowledge and skills and by creating tourism events, thus achieving economic benefits for the destination (Drpić, 2017; Andersson \& Lundberg, 2013, p. 102). The resource base is the fundamental element of the competitive ability of the destination, and includes culture, history and identity of the rural area, which is conditioned by a variety of historical influences and can be successfully presented through special events.

Tourism events based on heritage in rural areas represent a unique tourism product defined by specific features of the environment and heritage itself. Heritage is the destination's distinctive and unique resource element whose valorisation ensures increased competitiveness on the tourism market by offering a product of high value and recognition. Stipanović, Rudan, and Peršin (2015) underscore the importance of heritage-based events in destination branding. The specific features characterizing heritage-based tourism events in rural areas are specified by the following:

- events in rural areas are the result of people's lives through different historical periods in a given area;

- events make the local community proud of their own cultural and historical heritage and stimulate its preservation (especially folklore, historical events, culinary and religious events, etc.);

- heritage-based events must preserve their authenticity;

- events position the rural destination as the destination of culture and sustainable development;

- events add value to the existing tourism offer of the rural area;

- events create new tourist experiences that become motives for visiting the destination.

The basic assumption of a rural heritage-based tourism event is the active involvement of the local community, which can be achieved by timely information and education about the need to preserve and improve the local tourism offerings, rural areas and the elements of tangible and non-tangible heritage. The local community must be involved in every segment of event planning, organisation, management and development, as well as participate in the creation of corrective actions based on feedback from the tourism market. Heritage-based events represent an element for creating and promoting the desired identity of rural destinations and create higher value, which is reflected in the local quality of life and the upgrading of cultural tourism offerings, which in turn contributes to increased destination competitiveness and satisfaction of all stakeholders.

Figure 1 clearly shows that the prerequisite for competitive advantage is the sustainable and lasting synergy between tourism and heritage, which can be achieved through heritage-based events as the original and unique elements of rural destinations' tourism offerings. This is a mutually conditioned process based on the funnel principle, in which all the positive, as 


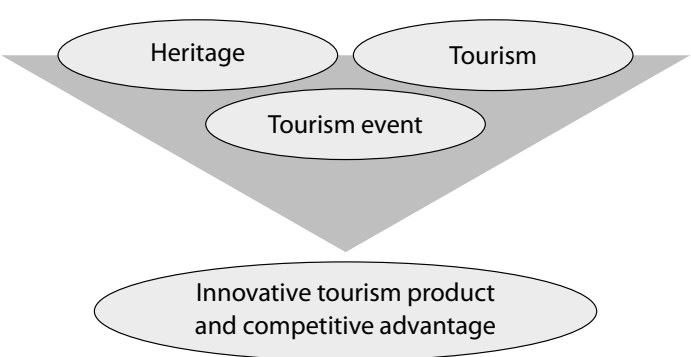

Figure 1 Competitiveness of Rural Tourism Destination: The Funnel Model

well as negative aspects of the observed elements are permeated and mutually complemented, creating a new recognisable tourism product by applying modern knowledge and skills.

Rural destination management must pay particular attention to determining the desired level of heritage involved in the tourism product and enable the sustainable development of tourism events, which can be achieved by incorporating international quality standards or by adopting unique quality standards for an individual event or destination. Interventions that might potentially endanger the value and originality of the tradition need to be prevented. Undesirable influences are possible already in the process of designing a tourism event and are wielded by entrepreneurs and marketing experts in order to achieve greater market attractiveness of the product and to realize greater economic benefits for the destination, creating false stories and distorted images of the role of tangible and non-tangible heritage in the life of the local community. In tourism event development, innovation is an essential driving force of evolution, in which systems adapt to internal changes or changes in the surrounding environment. Innovations take place in all areas of business, societal, cultural, social and private life, thus becoming a critical factor in economic development (Uran Maravić, Križaj \& Lesjak, 2015, p. 53).

One of the recognisable heritage and tourism events in rural Croatia is the Đakovo Embroidery Festival, boasting tradition, originality, and contributing to the economic and social advancement of the community for over half a century. For this reason, the authors have explored the visitors' satisfaction with cer- tain elements that affect the competitiveness of both Đakovo and the Đakovo Embroidery Festival (culture, history, infrastructure, accessibility, offer, hospitality, human resources development, information/research, quality of services, location, safety, image, value for money, etc.). The aim is to identify the current level of event recognition and to set guidelines for further improvement of rural Croatia's events on the tourism market.

\section{Đakovo Embroidery Festival: Tourism Event Based on Non-Tangible Rural Heritage}

Rural areas in Croatia organise several heritage-based events, but only a small number of them focus on potential tourists and are integrated into rural destinations' tourism offers. One of the numerous wellknown and valuable events presenting the cultural and historical values of Croatia is the Đakovo Embroidery festival, an essential event and symbol of the town of Đakovo. The first Slavonia and Baranja folklore festival, 'Đakovo Embroidery', was held on July 1967 as a specific cultural tourism event marking the International Tourist Year.

In 2016, the festival celebrated its 5oth anniversary. ${ }^{1}$ It includes many attractive events, including the ceremonial procession of all the participants, the opening and closing ceremonies, equestrian competitions, parade of the horse-drawn carts, gastronomic and musical programmes, and others. This festival was created and remained on the exceptionally strong foundations of folk heritage in Đakovo, for many reasons one of the most important centres of Croatian folklore. One of the symbols of Đakovo Embroidery, Ljelje (the Procession of Queens), has been inscribed on the World Heritage List. Every spring on Pentecost, Ljelje/Queens from Gorjani move in a procession from house to house, performing a ritual composed of special songs and dances with sabres (Min-

${ }^{1}$ According to the estimates in the Cultural Strategy of the City of Đakovo, Đakovo Embroidery gathers more than five thousand participants from all over Croatia, but also from abroad, and visitors can enjoy the beauty of folk customs, costumes, songs, dance, handicrafts, gastronomic specialties (Đakovo Tourist Board, personal communication, 2018). 
Table 1 Number of Arrivals and Overnight Stays in Đakovo 2010-2017

\begin{tabular}{|c|c|c|c|c|c|c|}
\hline \multirow[t]{2}{*}{ Year } & \multicolumn{2}{|c|}{ Whole year } & \multicolumn{2}{|c|}{$\begin{array}{c}\text { Đakovo } \\
\text { Embroidery } \\
\text { Festival }\end{array}$} & \multicolumn{2}{|c|}{$\begin{array}{c}\text { Đakovo } \\
\text { Embroidery } \\
\text { share (\%) }\end{array}$} \\
\hline & (1) & (2) & (1) & (2) & (1) & (2) \\
\hline 2010 & 6,898 & 3,417 & 1,063 & 567 & 15.41 & 16.59 \\
\hline 2011 & 7,290 & 3,815 & 1,422 & 782 & 19.51 & 20.50 \\
\hline 2012 & 7,336 & 4,153 & 1,228 & 662 & 16.74 & 15.94 \\
\hline 2013 & 9,315 & 5,206 & 1,818 & 996 & 19.52 & 19.13 \\
\hline 2014 & 11,021 & 5,690 & 1,607 & 868 & 14.58 & 15.25 \\
\hline 2015 & 14,027 & 6,597 & 2,239 & 1,228 & 15.96 & 18.61 \\
\hline 2016 & 14,489 & 7,518 & 2,602 & 1,521 & 17.96 & 20.23 \\
\hline 2017 & 19,518 & 8,965 & 4,137 & 2,040 & 21.20 & 22.76 \\
\hline Total & 89,894 & 45,361 & 16,116 & 8,664 & 17.93 & 19.10 \\
\hline
\end{tabular}

Notes Column headings are as follows: (1) overnight stays, (2) arrivals. Based on data from Đakovo Tourist Board (personal communication, 2018).

istry of Culture, 2018a). Another essential part of the festival is 'bećarac' - a vocal or vocal-instrumental song popular in Slavonia, Baranja and Syrmia, usually sung at weddings and other joyous occasions (Ministry of Culture, 2018b). Every year, Đakovo Embroidery also presents the cultural heritage from the Croatian diaspora; mostly Bosnia and Herzegovina, but also Australia and New Zealand, the United States, and Canada. Occasionally, folklore societies from Germany, Macedonia, Bosnia and Herzegovina, Slovenia, and New Zealand are also present, making Đakovo Embroidery an international event, increasing market recognition of Đakovo, Slavonia and the Republic of Croatia on the global tourism market. Positive impressions left on participants from abroad represent free advertising and word-of-mouth recommendations based on the non-tangible heritage of the Republic of Croatia.

Đakovo Embroidery has a significant impact on the overall tourism promotion of the area, which is also visible in the increased number of visitors to Đakovo during the event. According to Đakovo Tourist Board (personal communication, 2018), the number of festival visitors has been continuously increasing from 2015
Table 2 Number of Participants and Visitors to Đakovo Embroidery Festival

\begin{tabular}{lrrrr}
\hline Year & Participants & Est. no. of & \multicolumn{2}{c}{ Increase/decrease } \\
\cline { 4 - 5 } & & visitors & $(1)$ & $(2)$ \\
\hline 2015 & 2,739 & 80,000 & - & - \\
$2016^{*}$ & 3,363 & 100,000 & +22.78 & +25.00 \\
2017 & 2,743 & 110,000 & -18.74 & +10.00 \\
Total & 8,845 & 290,000 & - & - \\
\hline
\end{tabular}

Notes Column headings are as follows: (1) participants, (2) overnight stays. Based on data from Đakovo Tourist Board (personal communication, 2018).

to 2017. In the observed period, the number of visitors to the event is estimated at 290,000 (see Table 1 ).

In the observed period, the number of Đakovo Embroidery Festival participants differs only slightly, with the largest number recorded at the Festival's 5oth anniversary, when 3,336 participants attended the event. At the time of the event, the number of visitors, as well as overnight stays, increases with minor fluctuations. In 2010, there were 1,063 overnight stays and 567 arrivals, while 2017 recorded 4,137 overnight stays and 2,040 arrivals, representing a $289,18 \%$ increase of the number of overnight stays and $259,79 \%$ increase of the number of visitors. The number of arrivals in 2017 makes up for $21.20 \%$ of the total number of arrivals, and $22.76 \%$ of the total number of overnight stays, which makes a significant increase compared to 2010 when the ratios were $15.41 \%$ and $16.59 \%$, respectively (see Table 2).

\section{Methodology}

The authors conducted empirical research with primary data in which they used a structured questionnaire, translated and offered in the Croatian and English languages, to the participants who attended the event and who voluntarily agreed to participate in the research when asked. No difficulties occurred during the data gathering procedure. The questionnaire consisted of six parts; the first determining the sociodemographic characteristics of the respondents, followed by determining the motive of arrival to the destination and the event; the means of informing prior to the arrival to the destination; the way of arrival to 
the destination, and the level of satisfaction with the elements of the offer, which was determined using a Likert scale. The questions were prepared according to the methodologies of previously undertaken research studies such as том As (Institute for Tourism, 2008; 2018), Guidelines: Survey Procedures for Tourism Economic Impact Assessment of Gated Events and Festivals (Research Resolutions \& Consulting, 2007), and Getz (2010) in order to determine the necessity to know the socio-demographic characteristics of visitors as the basic element for creating a successful event. The main goal is to investigate the importance of satisfaction of the Đakovo Embroidery visitors and to determine the characteristics of the users of the Đakovo Embroidery service, in order to develop guidelines for further improvement of the tourism offerings and, consequently, a more competitive position of the city of Đakovo on the tourism market (Drpić, 2017). The collected research results were processed using SPSs 2.0, Arithmetic Mean and Standard Deviation, and Pearson's Coefficient of Correlation.

\section{Results}

During Đakovo Embroidery 2016, a random sample of 57 respondents was surveyed, ${ }^{2}$ of which women made up $52.6 \%$ and men $47.4 \%$. The average age of visitors is 39.11 years. As far as their educational structure is concerned, $36.8 \%$ of the respondents have a secondary education, $57.9 \%$ higher education and $5.3 \%$ of the respondents have a doctoral degree. In terms of the respondents' country of permanent residence, most are from Croatia (36.8\%), Slovenia (31.6\%), and Germany (15.8\%).

More than half of the respondents were visiting the Đakovo Embroidery festival for the first time (63.2\%), but there is also a significant proportion of those who visited the event several times (15.8\% twice, $15.8 \%$ five times and 5.3\% six times). It can be concluded that a quarter of the respondents are regular visitors to the event. The respondents mostly used hotel accommodation (42.1\%), private accommodation (31.6\%), and friends or acquaintances $(26.3 \%)$. Almost all the re-

\footnotetext{
${ }^{2}$ The results of the research were published as part of the $\mathrm{PhD}$ thesis (Drpic, 2017).
}

spondents came to the festival individually ( $84.2 \%)$, spending between one and two days in the destination.

Cultural heritage is the primary motive for coming to the city of Đakovo (36.8\%), while the primary motives for visiting Đakovo Embroidery are acquaintances' recommendation (36.8\%) and the image of the tourism event (21.1\%). Most of the respondents become informed about the Đakovo Embroidery festival via the internet $(42.1 \%)$ and television (31.6\%). This fact underscores the importance of modern information technology in the promotion of destinations and events, as well as pre-sale and post-sales activities, especially since the Đakovo Embroidery festival does not have an official website. Visitor consumption is an essential element in assessing the success of the event and its competitiveness, and in making decisions about event improvement. The results of the survey show relatively low visitor consumption in Đakovo. During their stay, the visitors intend to spend $€ 195.26$ of which the largest share is dedicated to transport, accommodation, and food. Interestingly enough, a significant part of the funds is spent on cultural contents (13.88\%), i.e. $€ 27.11$, of which $€ 14.47$ are to be spent at the event itself $(53.37 \%$ of the amount to be spent on culture and $7.41 \%$ of the total).

In order to make the right decisions for improving the existing tourism offer, destination management needs to be aware of the level of satisfaction with individual elements of the offerings and increase competitiveness on the tourism market by removing the weak points. The respondents evaluated each event element with scores from 1 to 5 , with -1 being 'very dissatisfied' and 5 'very satisfied.'

Table 3 shows that content recognition and quality are an essential element of event success. The respondents showed the highest level of satisfaction with interpretation quality of event participants/moderators - presenters, with a mean value 4.42 , followed by attractiveness of the event with a mean value of 4.26. The lowest level of satisfaction refers to information availability, for which the arithmetic mean of 2.21 indicates the need for a more active use of marketing and modern information technology. The respondents show a high level of satisfaction (3.53) with the image of the destination. 
Table 3 Level of Satisfaction with Individual Elements of Đakovo Embroidery

\begin{tabular}{|c|c|c|c|c|}
\hline Group & Elements & (1) & (2) & (3) \\
\hline \multirow{8}{*}{$\begin{array}{l}\text { Content } \\
\text { recognition } \\
\text { and quality }\end{array}$} & Recognition/image (prior to arrival) & 3.53 & 2.32 & 65.72 \\
\hline & Information availability & 2.21 & 2.62 & 118.55 \\
\hline & Quality of information/marketing materials & 3.21 & 0.98 & 30.53 \\
\hline & Event organisation quality & 4.00 & 0.58 & 14.50 \\
\hline & Event authenticity & 4.11 & 0.66 & 16.06 \\
\hline & Attractiveness & 4.26 & 0.45 & 10.56 \\
\hline & Interpretation quality of event participants/moderators - presenters & 4.42 & 0.51 & 11.54 \\
\hline & Total & 3.68 & 0.71 & 19.44 \\
\hline \multirow[t]{6}{*}{ Infrastructure } & Traffic accessibility & $4 \cdot 37$ & 0.76 & 17.39 \\
\hline & Safety & 4.79 & 0.42 & 8.77 \\
\hline & Cleanliness of attraction site & 4.16 & 0.50 & 12.02 \\
\hline & Cleanliness of sanitary facilities & 3.42 & 0.69 & 20.18 \\
\hline & Diversity of side events & 1.89 & 2.00 & 105.82 \\
\hline & Total & 3.73 & 1.02 & $27 \cdot 37$ \\
\hline \multirow{7}{*}{$\begin{array}{l}\text { Staff, pricing, } \\
\text { amenities }\end{array}$} & Opening hours of catering and hotel facilities & 2.58 & 1.35 & 52.33 \\
\hline & Prices of beverages or side products & 3.95 & 0.52 & 13.16 \\
\hline & Souvenirs & 3.95 & 0.70 & 17.72 \\
\hline & Staff friendliness & 3.53 & 0.84 & 23.80 \\
\hline & Staff knowledge and expertise & 3.11 & 1.88 & 60.45 \\
\hline & Value for money & 3.68 & 0.58 & $15 \cdot 76$ \\
\hline & Total & 3.47 & 0.49 & 14.08 \\
\hline \multicolumn{2}{|c|}{ Overall satisfaction level } & 3.53 & 0.51 & $14 \cdot 45$ \\
\hline
\end{tabular}

Notes Column headings are as follows: (1) average satisfaction score, (2) standard deviation, (3) correlation coefficient.

Another highly rated element is the attractiveness of the event (4.26), suggesting that a varied programme, especially if based on original heritage, can result in high visitor satisfaction. The respondents are also very satisfied with event authenticity (4.11) and event organisation quality (4.00). Mean deviation from the average level of satisfaction with the recognition and quality of the Đakovo Embroidery festival is 0.71 . Variability of visitor satisfaction with content recognition and quality is relatively low.

When it comes to infrastructure, the respondents show the highest level of satisfaction with safety (4.79). The respondents are generally very satisfied with Đakovo infrastructure (3.73). It should be noted that the cleanliness of the attraction site (4.16), the cleanli- ness of sanitary facilities (3.42) and traffic accessibility (4.37) are all highly rated. The lowest level of satisfaction refers to the diversity of side events, with a mean value as low as 1.89 .

Mean deviation from the average level of satisfaction with the staff, pricing and amenities is 0.49 . The variability of visitor satisfaction with infrastructure is relatively low. The highest level of satisfaction (3.95) is with prices of beverages and side products. The lowest level of satisfaction refers to souvenirs (2.47), indicating the current lack of original souvenirs in the tourism offering and the need to design and offer them. The visitors are mostly satisfied (2.58) with the opening hours of catering and hotel facilities. This indicates that destination management, in agreement 
with the local authorities, needs to change the current opening hours of catering facilities. The visitors are satisfied with value for money (3.68) and staff friendliness (3.53). Although the respondents are satisfied with staff quality, it is not at a satisfactory level given that staff knowledge and expertise are rated 3.11, indicating the need for further investment in education and quality of human resources in the destination. The mean deviation from the average level of satisfaction with the infrastructure of Đakovo Embroidery is 1.02, while the variability of visitor satisfaction with staff, pricing, and amenities is relatively low. The overall level of satisfaction with the event is high, with arithmetic mean 3.53. It can be concluded that $52.6 \%$ of all surveyed respondents are very satisfied with their visit to Đakovo Embroidery, while $47.4 \%$ are satisfied. Mean deviation from the average level of overall satisfaction with the event is 0.51 , and variability of overall visitor satisfaction with the event, in general, is relatively low. The development and long-term sustainability of rural heritage-based tourism event can only be ensured if there are clear standards and measures for achieving a competitive and recognisable rural tourism range of tourism offerings.

\section{Opportunities for Event Development - The Example of Đakovo Embroidery}

In order to ensure a sustainable competitive position on the market characterised by constant changes, new forms of tourism demand, and an abundance of competitors, rural tourism destinations need to design a model for evaluating the quality of contents and elements of rural heritage-based tourism events.

The process of creating a heritage-based tourism event is complex and demanding and requires a variety of knowledge and skills from destination management, as well as modern technology solutions such as interactive web sites, applications, virtual tours of Đakovo and Đakovo Embroidery, etc.

In addition, it is necessary to ensure a permanent and consistent quality of planning, organisation, implementation, information and monitoring, as well as corrective activities. Unfortunately, there is no statistical monitoring of the number of event visitors, which prevents the creation of appropriate develop- ment plans and strategies. Event development could be steered by international or national quality standards, such as ISO 20121 for sustainable event management, designed in 2012 at the time of the Olympic Games in London, and applied during the Eurovision Song Contest in Stockholm, achieving enviable results in sustainability management, especially in reducing the use of hazardous waste materials, energy consumption, and exhaust gases. By using only biodegradable materials for beverages, the organizers prevented the creation of two tons of waste, while energy saving was achieved by using special water heating systems and encouraging the use of local food (see https://www .iso.org/iso-20121-sustainable-events.html).

In addition to international Iso standards, it is possible to design internal or national standards that are more closely tailored to the needs of the local community and the local tourism market. One example of a possible standardisation system in Croatia presented in this paper is the CroRuralisHeritage program. The basic purpose of certification is to achieve greater transparency and added value for all stakeholders in the Đakovo destination, but it must be subject to permanent improvements using feedback systems and modern information technologies. Value assessment of the Đakovo Embroidery festival would be performed by evaluating the three groups of parameters on which Đakovo Embroidery is based: heritage (tangible and intangible), event (Đakovo Embroidery) and rural destination (Đakovo). See Table 4.

The certification committee could include:

- Representatives of the Đakovo Tourist Board

- Representatives of the Đakovo city

- Representatives of cultural workers

- Representatives of tourism workers

- Representatives of scientists and professionals

- Local community - participation in public discussion of the assessment results

Each representative could award points that would affect the final result at a predetermined rate, with the aim of preventing individual preferences and bias. One essential element for event certification of the Đakovo Embroidery festival is its influence on the sustainable destination development of Đakovo, as well as 
Table 4 Đakovo Embroidery certification parameters

\begin{tabular}{lll}
\hline Heritage (30) & Event (30) & Rural destination (40) \\
\hline Heritage preservation. & Economic sustainability of the event. & Attitudes of the local community. \\
Effects of previous reconstructions. & Implementation of international and & Tourism event harmonization with \\
Heritage repurpose possibility. & national quality standards & local development strategies and the \\
Adopted destination strategy for & Environmental responsibility (REs, & existing tourism product. \\
sustainable heritage management. & green perspectives ...). & \\
Economic performance of heritage. & Development opportunities & \\
& infrastructure. & \\
\hline
\end{tabular}

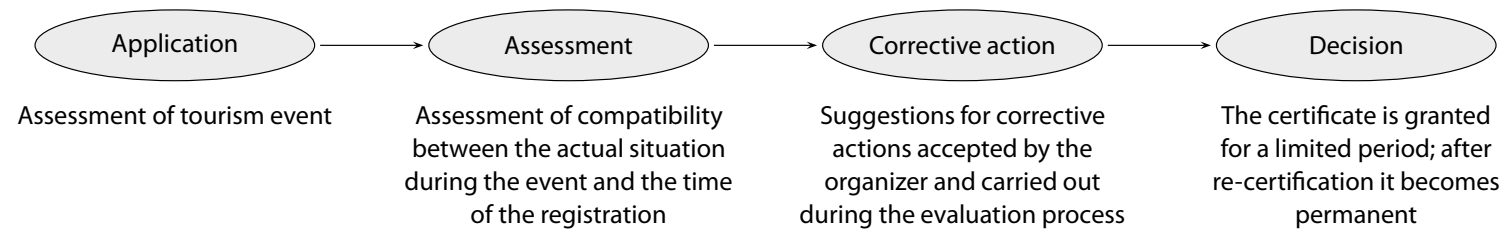

Figure 2 Application process for CroRuralisHeritage certification

the sustainable management of tangible and intangible heritage in the overall micro and macro environment. The purpose of event assessment by the certification board is to determine the weak links in the chain in order to remove them, and to emphasise the strong links as the basis for the creation of competitive advantage. The CroRuralisHeritage certification process is conceived as a national system for evaluating heritage-based tourism events held in Croatian rural areas, facilitating the promotion on the tourism market through CroRuralisHeritage brand. The process of obtaining a certificate is conceived as a several months-long process that would begin no later than six months prior to the event. A heritage-based event would be applied by either the event organizer or a target group within the destination.

The assessment of comparability between the application and the actual situation would be carried out by an assessment team that would, based on the discrepancies noted, draw up a list of corrective actions that the organizer would have to conduct before the end of the current event. After the proposed corrections are implemented, the organiser invites the evaluators to carry out the final evaluation of the event and make the decision about awarding the CroRuralisHeritage certificate. The certificate is awarded for one year, followed by a re-evaluation process. A re-awarded certificate is considered permanent and can only be denied in case of breaching of the basic principles of certification (i.e., violation of heritage authenticity, the rural area, and the general resource base) (Figure 2).

\section{Conclusion}

Although comprising a significant part of the Croatian territory, rural areas are not sufficiently recognized and included in the tourism offerings; most of the tourist traffic continues to take place in seaside destination and resorts.

Culture and heritage represent essential elements in preserving the tradition and strengthening local identity as a prerequisite for creating a permanently successful heritage-based tourism event and guaranteeing its sustainability on the market. Considering that the rural area is rich in heritage and has a preserved resource base, it is an ideal area for improving the existing tourism offer of the Republic of Croatia. This paper presents the Đakovo Embroidery festival as a tourism event model whose success and longevity are based on heritage and which represents an essential factor in the preservation of heritage, especially its most vulnerable aspect: intangible heritage.

The limitation of this research lies in its small 
number of respondents, and further research should be directed to other destination stakeholders, such as local population, participants, and management. The research should be repeated in a reasonable period on a larger statistical sample. Research accuracy would be improved by the organisers' more precise statistical tracking of number of visitors, since it is now only based on estimation. The authors, therefore, suggest implementation of possibly on-line or application-based registration of visitors before they come to the event. The research has pointed to the importance of using modern means of communicating with the market through websites, social networks, Q bar codes, smartphone app development, and the like. The Đakovo Embroidery Festival is only present on Facebook, and does not have its own web site or mobile app, which makes it challenging to achieve a sufficient level of presence in the media of the event itself, thereby disrupting its actual developmental and competitive potential on the market. This is also perceived as one of the significant shortcomings of the event.

The implementation of the proposed certification program CroRuralisHeritage would enhance rural tourism destination recognition, the creation of added value of the overall tourism product and long-term sustainability of the destination, heritage and tourism events. The process of designing a heritage-based tourism product must be based on feedback from the target market and the local community, allowing the destination management to take timely corrective action in order achieve sustainable management of the rural heritage-based tourism event.

\section{References}

Andersson, T. D., \& Lundberg, E. (2013). Commensurability and sustainability: Triple impact assessments of a tourism event. Tourism Management, 37, 99-109.

Bowdin, G., Allen, J., O’Toole, W., Harris, R., \& McDonnell, I. (2008). Events management. Oxford, England: Elsevier.

Crouch, G. I., \& Brent Ritchie, J. R. (1999). Tourism, competitiveness, and societal prosperity. Journal of Business Research, 44(3), 137-152.

Crouch, G. I., \& Brent Ritchie, J. R. (2003). The Competitive destination: A sustainable tourism perspective. Wallingford, England: CA B I.
Daniloska, N., \& Hadzi Naumova-Mihajlovska, K. (2015). Rural tourism and sustainable rural development. Economic Development, 17(3), 307-320.

Dashper, K. (2014). Introduction: Rural tourism: Opportunities and challenges. In K. Dashper (Ed.), Rural tourism: An international perspective (pp. 1-19). Cambridge, England: Cambridge Scholars Publishing.

Davidson, R., \& Rogers, T. (2006). Marketing destinations and venues for conferences, conventions and business events. New York, NY: Butterworth-Heinemann.

Demonja, D. (2014). The overview and analysis of the state of rural tourism in Croatia. Sociology and Space, 52(1), 69-9o.

Drpić, D. (2017). Turistički događaji temeljeni na baštini $i$ konkurentnost turističke ponude (Unpublished doctoral dissertation). University of Rijeka, Opatija.

European Commission. (2017). Rural areas and the primary sector in the EU. Retrieved from https://ec.europa.eu/ agriculture/sites/agriculture/files/statistics/facts -figures/eu-rural-areas-primary-sector.pdf

Eurostat (2017a). Statistics on rural areas in the EU. Retrieved from http://ec.europa.eu/eurostat/statistics-explained/ index.php/Statistics_on_rural_areas_in_the_EU

Eurostat $(2017 \mathrm{~b})$. Tourism statistics at regional level. Retrieved from http://ec.europa.eu/eurostat/statistics -explained/index.php/Tourism_statistics_at_regional _level

Getz, D. (2010). Event management \& event tourism. New York, NY: Cognizant Communication Corporation.

Getz, D., \& Page, S. J. (2016). Event studies: Theory, research and policy for planned events. London, England: Routledge.

Goeldner, C., \& Ritchie, B. (2006). Tourism principles, practices, philosophies (1oth ed.). New York, NY: Wiley.

Gomezelj Omerzel, D. (2006). Competitiveness of Slovenia as a tourist destination. Managing Global Transitions, $4(2), 167-189$.

Institute for Tourism. (2008). TOMAs stavovi $i$ potrošnja posjetitelja kulturnih atrakcija i događanja u Hrvatskoj. Retrieved from http://www.iztzg.hr/UserFiles/File/ novosti/2009_TOMAS_Kulturni_turizam_2008 _Sazetak_i_Prezentacija.pdf

Institute for Tourism. (2018). Tomas summer 2017 - Attitudes and consumption of turists in Croatia. Retrieved from http://iztzg.hr/UserFiles/File/Narudzbe/Tomas-Ljeto -2017-Stavovi-i-potrosnja-turista-u-Hrvatskoj.pdf

Ivančić, I. (2015). Međuovisnost turističkih događaja u okruženju $i$ uspješnost hotelijerstva (Unpublished doctoral dissertation). University of Rijeka, Opatija, Croatia. 
Krajičkova, A., \& Šauer, M. (2018). Differences in motivation of food festivals visitors: A view from the Czech Republic. Geographica Pannonica, 22(3), 189-200.

Kušen, E. (2006). Ruralni turizam. In S. Čorak, \& V. Mikačić (Eds.), Hrvatski turizam: plavo, bijelo, zeleno (pp. 167189). Zagreb, Croatia: Institut za turizam Zagreb.

Ministry of Culture. (2018a). Godišnji proljetni ophod kraljice ili ljelje iz Gorjana. Retrieved from https://www.min -kulture.hr/default.aspx?id=5231

Ministry of Culture. (2018b). Bećarac - vokalno instrumentalni napjev s područja Slavonije, Baranje i Srijema. Retrieved from https://www.min-kulture.hr/default .aspx?id=7153

Ministry of Tourism. (2018). Croatian tourism in numbers 2017. Zagreb, Croatia: Author.

Research Resolutions \& Consulting. (2007). Guidelines: Survey procedures for tourism economic impact assessments of gated events and festivals. Retrieved from http://www .mtc.gov.on.ca/en/research/resources/Guidelines_Econ _Impact_Gated_Events_2007.pdf

Porter, M. E. (1990). The competitive advantage of nations. New York, Ny: Free Press.

Poslovni.hr. (2018). Ruralni turizam za veći razvoj treba potporu države i banaka. Retrieved from http://www .poslovni.hr/hrvatska/ruralni-turizam-za-veci-razvoj -treba-potporu-drzave-i-banaka-34070o

Ružić, P. (2011). Ruralni turizam Istre. Poreč, Croatia: Institut za poljoprivredu i turizam Poreč.

Sedmak, G., Planinc, T., Kociper, T., \& Planinc, S. (2015). Avtentičnost kot resurs podeželskega turizma. In G. Sedmak, D. Smolčić Jurdana, T. Kociper, \& T. Planinc (Eds.), Spodbujanje ruralnega turizma (pp. 89-97). Koper, Slovenia: Založba Univerze na Primorskem; Opatija, Croatia: Sveučilište u Rijeci.
Smolčić Jurdana, D. (2015). Ekonomska obilježja poslovanja u ruralnom prostoru - usporedba Hrvatske i Slovenije. In G. Sedmak, D. Smolčić Jurdana, T. Kociper, \& T. Planinc (Eds.), Spodbujanje ruralnega turizma (pp. 159-168). Koper, Slovenia: Založba Univerze na Primorskem; Opatija, Croatia: Sveučilište u Rijeci.

Stipanović, C., Rudan, E., \& Peršin, P. (2015). Festival tourism in the repositioning of Croatian tourism destinations. In S. Janković \& D. Smolčić Jurdana (Eds.), TOSEE Tourism in Southern and Eastern Europe 2015: 3rd International Scientific Conference; Sustainable Tourism, Economic Development and Qulity Life (pp. 355-367). Opatija, Croatia: University of Rijeka.

Svržnjak, K., Kasntar, S., Jerčinović, S., \& Kamenjak, D. (2014). Ruralni turizam: uvod u destinacijski menadžment. Križevci, Croatia: Visoko gospodarsko učilište u Križevcima.

Uran Maravić, M., Križaj, D., \& Lesjak, M. (2015). Innovation in Slovenian tourism organisations. Tourism \& Hospitality Management, 21(1), 51-62.

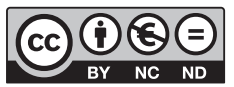

This paper is published under the terms of the Attribution- NonCommercial-NoDerivatives 4.0 International (CC B Y-NC-ND 4.0) License. 